\title{
U.S. Potential of Sustainable Backyard Distributed Animal and Plant Protein Production during and after Pandemics
}

\author{
Theresa K. Meyer ${ }^{1}$, Alexis Pascaris ${ }^{2}$ (D), David Denkenberger ${ }^{3,4}$ and Joshua M. Pearce $5,6,7, *$ (D) \\ 1 Department of Materials Science \& Engineering, Michigan Technological University, \\ Houghton, MI 49931, USA; tkmeyer@mtu.edu \\ 2 Department of Social Science, Michigan Technological University, Houghton, MI 49931, USA; \\ aspascar@mtu.edu \\ 3 Alliance to Feed the Earth in Disasters (ALLFED), Fairbanks, AK 99775, USA; ddenkenberger@alaska.edu \\ 4 Department of Mechanical Engineering and Alaska Center for Energy and Power, \\ University of Alaska Fairbanks, Fairbanks, AK 99775, USA \\ 5 Équipe de Recherche sur les Processus Innovatifs (ERPI), Université de Lorraine, 54000 Nancy, France \\ 6 School of Electrical Engineering, Aalto University, 02150 Espoo, Finland \\ 7 Department of Electrical \& Computer Engineering, Michigan Technological University, \\ Houghton, MI 49931, USA \\ * Correspondence: pearce@mtu.edu
}

check for updates

Citation: Meyer, T.K.; Pascaris, A.; Denkenberger, D.; Pearce, J.M. U.S. Potential of Sustainable Backyard Distributed Animal and Plant Protein Production during and after Pandemics. Sustainability 2021, 13, 5067. https://doi.org/10.3390/ su13095067

Academic Editor: Aitazaz A. Farooque and Farhat Abbas

Received: 16 March 2021

Accepted: 28 April 2021

Published: 30 April 2021

Publisher's Note: MDPI stays neutral with regard to jurisdictional claims in published maps and institutional affiliations.

Copyright: (c) 2021 by the authors. Licensee MDPI, Basel, Switzerland. This article is an open access article distributed under the terms and conditions of the Creative Commons Attribution (CC BY) license (https:// creativecommons.org/licenses/by/ $4.0 /)$.

\begin{abstract}
To safeguard against meat supply shortages during pandemics or other catastrophes, this study analyzed the potential to provide the average household's entire protein consumption using either soybean production or distributed meat production at the household level in the U.S. with: (1) pasture-fed rabbits, (2) pellet and hay-fed rabbits, or (3) pellet-fed chickens. Only using the average backyard resources, soybean cultivation can provide $80-160 \%$ of household protein and $0-50 \%$ of a household's protein needs can be provided by pasture-fed rabbits using only the yard grass as feed. If external supplementation of feed is available, raising 52 chickens while also harvesting the concomitant eggs or alternately 107 grain-fed rabbits can meet $100 \%$ of an average household's protein requirements. These results show that resilience to future pandemics and challenges associated with growing meat demands can be incrementally addressed through backyard distributed protein production. Backyard production of chicken meat, eggs, and rabbit meat reduces the environmental costs of protein due to savings in production, transportation, and refrigeration of meat products and even more so with soybeans. Generally, distributed production of protein was found to be economically competitive with centralized production of meat if distributed labor costs were ignored.
\end{abstract}

Keywords: food security; global catastrophic risk; resilience; pandemic; existential risk; COVID-19; soybeans; agriculture; chickens; rabbits; distributed production

\section{Introduction}

It is well-established that pandemics stress critical infrastructures and decision makers normally focus on hospitals and medical facilities [1-5]. This was again observed for the coronavirus disease 2019 (COVID-19) pandemic, which overwhelmed medical infrastructure at the regional level $[6,7]$. Food and agricultural infrastructures can also be challenged by pandemics for both humans [5,8] and animals [9,10]. During the COVID-19 pandemic, meat packing plants in particular were susceptible to rapid spread of the virus, as was observed in the U.S. [11,12], Canada [13], Spain [14], Ireland [15], Brazil [16], and Australia [17]. Meat packing plants have been some of the most highly concentrated producers of virus cases because of the low temperatures, close working conditions, strenuous physical demands of the job, and increased contaminated airflow within the plants [11,12]. One such meat packing plant in Triumph, Missouri reported 373 positive coronavirus cases [18]. Because more than eighty percent of the meat packing in the United States is conducted 
by only four companies $[19,20]$, it is not difficult to imagine a partial shutdown of the meat packing industry during a viral pandemic or another national crisis. This brings about many questions concerning the ability to produce enough protein for the nation to sustain a near total shutdown of the meat industry. Although it would be technically possible to provide all the protein necessary for the U.S. using plant materials [21,22], there is another option that may be more readily socially accepted in the U.S.: distributed production. During COVID-19, distributed production [23] was widespread to overcome supply shortages for personal protective equipment (PPE) [24-28], as well as medical equipment such as ventilators [29] and nasal swabs [30,31]. Conventional manufacturing normally occurs in a centralized factory with products being shipped to customers often over long distances, whereas, distributed manufacturing refers to manufacturing closer to the consumer (possibly even in the consumers' own homes) [26,32].

One practical option to safeguard against the challenges of a constrained meat industry is individual backyard rabbit and chicken farms or soybean production, which provides some food resilience for consumers in the case of strict lockdowns or a major food supply chain disruption. This idea appeared to be attractive to many people during COVID-19 pandemic as there were shortages of supplies of both animals and facilities (e.g., chicken coups) [33-37] and gardening supplies and seeds [38,39]. Those already involved in backyard meat production prove it is viable [40]—but is backyard protein production scalable to the national level? How much protein could be produced? How would it compare to the current system on sustainability metrics?

To answer these questions, this study analyzes the potential for three types of meat production at the household scale in the U.S.: (1) pasture-fed rabbits, (2) pellet and hay-fed rabbits, and (3) pellet-fed chickens, as well as backyard soybean production. For the first potential, the USDA Soil Survey is used to determine the potential rabbit yield per acre of different soil types, which is then quantified throughout the U.S. at the state level based on average yard sizes (and an additional method). For the second and third cases, these same yard sizes are used to determine meat yield assuming external feed is available. Lastly, the amount of protein that can be provided if the same surface area is used for soybean production is calculated. The results of this technical analysis are then evaluated in terms of percent protein of USDA requirements, economic viability, and environmental sustainability compared to the current meat systems. The results are discussed in the context of the potential for backyard meat production to aid in food supply resiliency in the face of pandemics and their aftermaths, as well as policies that would maximize benefits and minimize drawbacks to the approach.

\section{Materials and Methods}

The average United States (hereafter American) home has a yard measuring between $809 \mathrm{~m}^{2}$ [41] and $1010 \mathrm{~m}^{2}$ [42]. The size of the average American yard is calculated by omitting people in communal living arrangements with no yards such as apartment buildings. While cattle and other large animals need over an acre of land to graze and roam [43], small-statured livestock including chicken and rabbits need considerably less space in comparison [44]. Considering this, three types of distributed meat production were evaluated: (1) free range rabbit, which only used the locally produced plant matter for feed; (2) pellet-fed rabbit, which used the locally produced plant matter in individual yards as well as external feed, and (3) chickens, which used only external feed, but produced both eggs and meat. Then the amount of protein that can be provided if the same surface area is used for soybean production is calculated.

\subsection{Pasture-Fed Rabbit Methods}

\subsubsection{Pasture-Fed Rabbits Method 1: Soil Survey}

First, to examine the possibility of pasture-fed rabbit farming in backyards across America, the USDA Web Soil Survey [45] was used to determine the highest grass density in multiple regions and climates in the country. A map generated by Ricker in 2007 from 
the National Institute of Standards and Technology detailing different soil types was used to characterize states into major soil types and terrains. Alabama, Ohio, Vermont, Oregon, Kansas, and Wyoming were selected as representative states for their respective soil types. Selection was made based on the percentage of the state represented by a soil type, the location of the state compared to other states with the same soil type, and data available within each state in the Web Soil Survey (sufficient data were not available for some states).

Representative cities were then selected within each state. Selection was made by using the city within the state with the median city size to determine what a typical town or living situation may be in that state. The cities (respective of the states listed above) of New Brockton (Alabama), Botkins (Ohio), Irasburg (Vermont), New Hope (Oregon), Fairview (Kansas), and Nordic (Wyoming) were used. The city addresses were then input into the Web Soil Survey and each area was examined for a primary forage type (either alfalfa hay, alfalfa, or pasture grass were used in this study) and the following equations were used to convert the vegetation data into the number of pasture-fed rabbits that could be supported per acre in each area during a growing season.

The total $\mathrm{kg}$ of wet alfalfa/acre/day (A) is given by:

$$
\mathrm{A}=\frac{\left(\frac{3.333 \mathrm{x}}{0.00110231}\right)}{\mathrm{G}}[\mathrm{kg} / \mathrm{acre} / \text { day }]
$$

where $x$ is the Imperial tons of dry alfalfa/acre/year and $G$ is the number of days in a growing season. Dry alfalfa is the dry weight of the plant matter, which is multiplied by 3.333 to get wet weight assuming $33 \%$ dry matter [46].

The minimum and maximum values from Equation (1) give a comprehensive range, which are then used to calculate the number of rabbits that can be supported in the average American backyard. These calculations assume that an adult rabbit needs $25 \mathrm{~g}$ of dry food per day per $1 \mathrm{~kg}$ body weight [47]. The weight of a rabbit is assumed to be $3.2 \mathrm{~kg}$ on the heavier rabbit size within the range of rabbit weights [48]. The water content of grass is also required and a range of $0.7-0.86 \mathrm{~g}$ of water per grams of wet leaf is used [49]. The food mass required to feed an average rabbit for one day is given by:

$$
\mathrm{F}=\frac{\mathrm{wf}}{\mathrm{P}_{\mathrm{dry}}}[\mathrm{kg}]
$$

where $\mathrm{F}$ is the wet food mass required to feed an average ( $3.2 \mathrm{~kg}$ ) rabbit for one day, w is the weight of an average rabbit, $\mathrm{f}$ is the number of $\mathrm{kg}$ of dry food an average rabbit requires per day per $\mathrm{kg}$ body weight $(0.025 \mathrm{~kg})$, and $\mathrm{P}_{\mathrm{dry}}$ is the percent of dry matter in grass $(0.14-0.3)$.

The lowest and highest values given for maximum mass wet grass per day during the growing season are calculated from the Web Soil Survey [45]. The range for average yard size is also used to obtain the mass in $\mathrm{kg}$ of grass produced per yard is given by:

$$
\mathrm{k}=\left(\mathrm{y}_{\mathrm{m}} \times 0.000247\right) \mathrm{S}[\mathrm{kg}]
$$

where $\mathrm{k}$ is the number of $\mathrm{kg}$ of wet grass produced per yard, $\mathrm{y}_{\mathrm{m}}$ is the range of yard size in square meters, the numerical value of 0.000247 is the conversion factor to acres, and $\mathrm{S}$ is the value of $\mathrm{kg}$ wet grass produced per day from the Web Soil Survey.

With these two values from Equations (2) and (3), the number of rabbits that can be fed continuously on an acre and in an average American backyard can be calculated by:

$$
\mathrm{R}_{\text {yard }}=\frac{\mathrm{k}}{\overline{\mathrm{F}}}[\text { rabbits } / \text { yard }]
$$

where $R_{y a r d}$ is the number of rabbits fed continuously in an average American backyard and $\mathrm{k}$ and $\mathrm{F}$ are taken from Equations (2) and (3). 
To find the average number of rabbits sustained per acre, the following equation is used:

$$
\left.\mathrm{R}_{\mathrm{acre}}=\frac{\mathrm{S}}{\mathrm{F}} \text { [rabbits/acre }\right]
$$

where $R_{a c r e}$ is the number of rabbits fed continuously on an acre of grass, $S$ is the range of values taken from the Web Soil Survey results, and F is from Equation (2).

Certain soil types and states were not considered in this study because they would not facilitate the growth of enough vegetation to support the grazing of animals. Gray Desert Soils covering significant portions of the states of Nevada, Arizona, and New Mexico, and Nebraska Sand Hills covering Nebraska were discounted from the study. Discounting these states and their populations removes approximately 14.39 million people and $4.38 \%$ of the population of the Unites States.

Then using the acres available in each state and the expected yields in rabbits, the total annual pasture-fed rabbit production was calculated for the U.S. per year following:

$$
\mathrm{t}_{\text {region }}=\mathrm{R}_{\text {acre }} \times \mathrm{a}[\text { rabbits }]
$$

where $t_{\text {region }}$ is the number of rabbits sustained in a certain region/soil type, $R_{a c r e}$ is the number of rabbits per acre given from the equation above (5), and a is the number of acres within the soil type.

When this has been performed for each region as denoted by soil type, those values can be added together to show how many rabbits can be raised with no supplemental food in the entire U.S. for one year, $R_{U S}$ - pasture, following Equation (7).

$$
\mathrm{R}_{\mathrm{US}-\text { pasture }}=\sum_{\mathrm{n}=1}^{\mathrm{T}} \mathrm{t}_{\mathrm{n}}[\text { rabbits/year }]
$$

where $\mathrm{n}$ is the region and $\mathrm{T}$ is all of the regions (6 regions). Pasture-fed rabbits take 26-28 weeks to grow to the appropriate size for slaughter [48]. Using the information above, only one cohort of pasture-fed rabbits can be raised per year as a growing season for grass and alfalfa is stated as 180 days (about 26 weeks).

For pasture-fed rabbits the value for average yard size in the U.S. was used because rabbits grazing in the entire yard is the lowest maintenance option and the largest number of rabbits can be sustained this way. Implementing this option raises many other factors to consider such as predators invading rural yards and properly fenced in yards to prevent animal escape. According to the equations above, most American yards can sustain at least 1 rabbit fully free range for one year based on these conservative assumptions. A less-conservative method is based off an average grass growth and shown below.

\subsubsection{Pasture-Fed Rabbits Method 2: Average Growth}

Another analysis of grass growth by the British Ecological Society showed much higher values of average grass growth across the United States. This study states that the net primary production in the temperate zone of lawns is approximately $1000-1700 \mathrm{~g} / \mathrm{m}^{2}$ per year dry matter [50]. Temperate grassland areas have growth measured to be $100-1500 \mathrm{~g} / \mathrm{m}^{2}$ pear year of dry matter [50]. Tropical grasslands produce between 200 and $2000 \mathrm{~g} / \mathrm{m}^{2}$, and pasturelands have growth rates consistent with those of grasslands depending upon latitude [50].

In the United States, climate varies drastically throughout different states. The above ranges are averages to most accurately represent the climate in different areas of the U.S. The average value of growth is $1083 \mathrm{~g} / \mathrm{m}^{2}\left(38.2\right.$ ounces $\left./ \mathrm{m}^{2}\right)$ dry per year, based on the lawn and temperate and tropical grassland averages in [50].

\subsection{Pellet-Fed Rabbits Maximum}

For pellet-fed rabbits and chickens, it was assumed that only half of the average yard size will be used for animal production since both of these animals require sizable houses or pens and do not need to roam a vast area to obtain their food. Average American yard 
size is $809-1010 \mathrm{~m}^{2}$ [41,42,51]. Using the range given above, there is an available caged animal farming area of $405-505 \mathrm{~m}^{2}$. While this is the absolute maximum area that may be occupied for the purpose of this study, the number of animals able to be maintained in this area is not generally practical assuming that the person raising rabbits has career obligations other than rabbit farming full time.

Non-free-range rabbits require much less space than pasture-fed rabbits as their diet is not the determining factor of their living space. Depending on the size and weight of rabbit, desired quality of life for each animal, and method of raising, rabbits need anywhere from $0.14-3.70 \mathrm{~m}^{2}$ of land to exercise and live when they are hay and pellet fed $[47,48,52,53]$. This area is usually split between a caged area and a run. The large range of values is produced by sources omitting the run entirely. Wire cages are both recommended and discouraged as different breeders have different recommendations [47,53]. While a run is not essential for rabbit growth, omitting a run may lead to lower quality meat due to muscle atrophy [52].

For the purposes of this study, values given for the area of rabbit cages by Michigan State University Extension are used [53]. These values range from $0.14-0.46 \mathrm{~m}^{2}$ per rabbit. It is also assumed that a run is required with an area of $2.5-3.0 \mathrm{~m}^{2}$ per rabbit [47,52].

With these values, total required area for one pellet-fed rabbit, $A_{p r}$ is:

$$
\mathrm{A}_{\mathrm{pr}}=\mathrm{A}_{\mathrm{c}}+\mathrm{A}_{\text {run }}\left[\mathrm{m}^{2}\right]
$$

where $A_{p r}$ equals the area required to house one pellet-fed rabbit, $A_{c}$ is the cage size in $\mathrm{m}^{2}$, and $\mathrm{A}_{\text {run }}$ is the desired run size per rabbit in $\mathrm{m}^{2}$. With the above ranges, each rabbit is allotted $2.64-3.46 \mathrm{~m}^{2}$ in total.

With these values, the number of rabbits that can be supported on half an American yard, $R_{\text {pellets/yard }}$ is calculated by the following equation:

$$
\mathrm{R}_{\text {pellets } / \text { yard }}=\frac{\mathrm{A}_{\mathrm{y}} / 2}{\mathrm{~A}_{\mathrm{pr}}}[\text { rabbits }]
$$

where $A_{y}$ is the area of the average American yard $\left(809-1010 \mathrm{~m}^{2}\right), A_{p r}$ is defined above, and $R_{\text {pellets/yard }}$ is the number of pellet-fed rabbits that can be sustained at one time in half the average American yard. Pellet-fed rabbits only take 12 weeks to grow to appropriate size for slaughter [48] and since pellet-fed rabbits do not require grass as their main source of nutrition, 4 cycles of pellet-fed rabbits can be raised in a year if slaughtered at 12 weeks for each. Therefore, the total rabbits able to be harvested per acre per year in the U.S. is $4 \times \mathrm{R}_{\text {pellets/yard }}$ and the total pellet fed rabbits is

$$
\mathrm{R}_{\text {US-pellets }}=4 \times \mathrm{R}_{\text {pellets } / \text { yard }} \times \mathrm{n}_{\text {yard }} \text { [rabbits } / \text { year] }
$$

where $\mathrm{n}_{\mathrm{yard}}$ is the number of yards in the U.S.

\subsection{Chickens Maximum}

Industry stocking density for chickens is limited to less than 1 square foot per bird for all birds under 7 pounds [54]. This high density causes health problems such as leg deformities, broken bones, lack of social behavior with other birds, and can result in lower bodyweight and limited feed consumption $[54,55]$. To be considered free-range in industry, chickens need $0.30 \mathrm{~m}^{2}$ (3.25 square feet) [56]. In industry, chickens are raised for meat or eggs, but not usually both.

Chickens raised only for meat (referred to as Broilers in industry) are slaughtered between 5 and 18 weeks whereas chickens raised for eggs are allowed to produce for as long as 72 weeks before being slaughtered $[57,58]$. For this study, it is assumed that chickens will be raised for one year (from hatchlings). Chickens begin producing eggs around 18 weeks of age and this study assumes they will be slaughtered at 1 year of age to maximize both meat quality and egg production. 
Backyard chickens can be raised multiple different ways. Fully free-range chickens require supplemental feed and can either have space limitations or not. Chickens raised fully free-range have virtually unlimited space with a large coop to sleep in during the night that serves as protection from predators and the elements, and are fed kitchen scraps or some pellet feed to balance out a natural diet of insects, weeds, and other naturally occurring material [59]. Limited free-range raised chickens have only a coop and a small run to live in and are fed kitchen scraps and pellet feed for their entire diet [55]. Limited free-range chickens are most common in city or town settings and will be used for all calculations regarding obtainable protein from chicken meat and eggs because they are more accessible to most of the U.S. population.

The suggested density for a limited free-range chicken setup that can be applied most easily to backyard chicken production is no more than 13 birds per $\mathrm{m}^{2}$ for the enclosed area with access to an open-air area with a density of no more than 1 bird per $\mathrm{m}^{2}$ [55]. To remain conservative, each chicken is allotted approximately $1.08 \mathrm{~m}^{2}\left(1.29\right.$ yards $\left.^{2}\right)$ of space, which provides a square meter outside and $1 / 13$ th of a meter of enclosure. With this information, the following equation can be used to determine the maximum number of chickens that can fit in half of an average American yard:

$$
\mathrm{C}_{\text {yard }}=\frac{\mathrm{A}_{\mathrm{y}} / 2}{1.08}[\text { chickens }]
$$

The value for number of chickens found with Equation (11) is used to calculate the number of eggs available to each household per year. These calculations are performed assuming that meat chickens and egg producing chickens are the same and that chickens can produce eggs until they are slaughtered for meat. Chickens do not begin producing eggs until 18 weeks of life, meaning that their egg production (if raised from chicks that are hatched on day 1 of each year) lasts approximately 35 weeks.

\subsection{Realistic Backyard Capacity for Pellet-Fed Rabbits and Chickens}

Capacity for raising the maximum number of chickens or pellet-fed rabbits in most American backyards is unrealistic considering the time required to maintain that many animals. The equations below determine the number of animals required to produce $100 \%$ of the protein required to fulfill everyone in America for one year. These values are more than actually required as some protein is obtained from other food sources.

The average person consumes $51 \mathrm{~g}$ of protein per day (average of $56 \mathrm{~g}$ per day for the average sedentary man and $46 \mathrm{~g}$ per day for the average sedentary woman) which amounts to $18,615 \mathrm{~g}$ of protein per year per person [60]. This value is used for the calculations of percent of protein/year/household. The population of America is 328.2 million [61]. A household is defined by the U.S. Census Bureau as one or more people living in the same housing unit. There were 128.58 million households in the Unites States in 2019 [62]. By this definition, the average household contains 2.6 people.

To calculate the amount of protein required to feed the entire American population, the equation below is used:

$$
\mathrm{P}_{\mathrm{T}}=365 \times \mathrm{P} \times \mathrm{p} \text { [grams] }
$$

where $\mathrm{P}_{\mathrm{T}}$ equals the total amount of protein required to sustain the U.S. population for one year, 365 is the number of days in a year, $P$ is the U.S. population, and $p$ is the number of grams of protein required per person per day.

$\mathrm{P}_{\mathrm{T}}$ is used for calculations regarding number of chickens and number of pellet-fed rabbits. To calculate the number of chickens required to fulfill this entire protein need, Equation (13) below is used.

$$
\mathrm{C}=\frac{\mathrm{P}_{\mathrm{T}}}{35 \times \mathrm{P}_{\mathrm{E}} \times \mathrm{A}_{\mathrm{EPW}}+\mathrm{P}_{\mathrm{C}}}[\text { chickens }]
$$


where 35 is the number of weeks in a year that each chicken produces eggs, $\mathrm{P}_{\mathrm{E}}$, equal to 6.28 , is the number of grams of protein in one egg, $A_{\mathrm{EPW}}$, equal to the number of eggs produced in one week, $\mathrm{C}$ is the number of chickens to be raised in one year, and $\mathrm{P}_{\mathrm{C}}$, equal to 140.8 , is the number of grams of protein in the meat of one chicken.

To calculate the number of eggs per year, $E_{P Y}$, is:

$$
\mathrm{E}_{\mathrm{PY}}=35 \times \mathrm{A}_{\mathrm{EPW}} \times \mathrm{C}[\text { eggs per year }]
$$

where $E_{P Y}$ is equal to the number of eggs produced per year, 35 is the number of eggproducing weeks that each chicken has in one year, and $C$ is the number of chickens being raised.

For rabbits, the average number of animals to be raised for $100 \%$ protein production is determined by:

$$
\mathrm{R}=\frac{\mathrm{P}_{\mathrm{T}}}{\mathrm{P}_{\mathrm{R}}}[\text { rabbits }]
$$

where $\mathrm{P}_{\mathrm{T}}$ is equal to $6.11 \times 10^{12}$ as given by Equation (15) and represents the total amount of protein required to sustain the country for one year, $P_{R}$, equal to 445.5 , is the average of the range for protein value of one rabbit (297-594 g), and $R$ is the number of rabbits required to sustain the entire population for one year.

For both of the above equations, once the total number of animals required to sustain protein requirements is determined, that value is plugged in for $\mathrm{A}$ in the following equation to determine the number of animals per household required to meet this need.

$$
\mathrm{A}_{\mathrm{hh}}=\frac{\mathrm{A}}{128,580,000}[\text { animals per household }]
$$

where $\mathrm{A}$ is the number of animals (rabbits or chickens) required to sustain the entire population's protein requirements for one year, 128,580,000 is the number of households in America, and $\mathrm{A}_{\mathrm{hh}}$ is the number of animals to be raised per household.

To determine the total protein produced per household per year, $A_{h h}$ should be multiplied by the given value for $g$ protein per raw item.

To confirm the percent protein that will be provided by the identified number of animals, the following equation should be used.

$$
\mathrm{P}_{\mathrm{p}}=\frac{\mathrm{A}_{\mathrm{hh}} \times 128,580,000}{\mathrm{P}_{\mathrm{T}}} \times 100 \text { [percent protein] }
$$

where $P_{p}$ represents the percent protein that is supplemented by a specific protein source. This equation should confirm that the value for rabbits per household correctly provides $100 \%$ of the protein requirements and shows the percentages of protein that are provided by chicken meat and eggs, respectively.

\subsection{Backyard Soybean Production}

Land requirements to produce animal protein is 6-17 times greater than for soy protein, demonstrating the potential for plant-based foods to offset natural resource demands and extensive land use [63]. Because of this, a situation in which backyards are used to grow soybeans is modeled below. Soybeans are extremely rich in protein and contain about $40 \%$ consumable protein by calories [64]. Since chicken meat is approximately $80 \%$ protein [65], it can be assumed that double the soybeans (in terms of grams of dry food) would need to be produced to supply equal protein. The half yard statistic of $405-505 \mathrm{~m}^{2}$ is used for the calculations below. To grow a recommended number of soybeans to supplement into a normal diet, $4-8$ soybean plants should be grown per household member which only provides a small percentage of necessary protein [66]. If soybeans are planted with a spacing of 3.5 plants per foot in rows that are separated by 15 inches, 122,000 plants per acre can be produced [67]. One acre is $4046 \mathrm{~m}^{2}$, meaning that roughly 30 plants can be planted in 1 square meter of space and 12,100-15,200 plants could fit in half of the average 
backyard. Each plant typically produces $25-40$ pods in a harvest (one season). This means that one backyard could produce between 304,000 and 606,000 pods per season.

100 soybean pods and the beans within the pods were massed on a digital scale $(+/-0.1 \mathrm{~g})$ to obtain $\mathrm{m}_{\text {pod }}$, the beans were counted and massed to obtain $\mathrm{m}_{\text {bean }}$ and the number of beans/pod ( $\left.\mathrm{n}_{\text {bean/pod }}\right)$, respectively. Commercial soybeans have a rated protein density ( $\mathrm{d}_{\text {soy }}$ ) of $9.46 \mathrm{~g}$ protein per $100 \mathrm{~g}$ of wet soybeans [68]. Thus, the protein per pod, $P_{\text {pod }}$ is:

$$
\mathrm{P}_{\text {pod }}=\mathrm{m}_{\text {bean }} \times \mathrm{n}_{\text {bean } / \text { pod }} \times \mathrm{d}_{\text {soy }}[\mathrm{g} \text { protein per pod }]
$$

Therefore, the protein per yard from soybeans $\mathrm{P}_{\text {soy/yard }}$ is given by:

$$
\mathrm{P}_{\text {soy } / \text { yard }}=\mathrm{P}_{\text {pod }} \times \mathrm{N}_{\text {pods/year/yard }}[\mathrm{g} \text { soy protein per average yard/year }]
$$

Finally, with humans needing $51 \mathrm{~g}$ protein per day, the number of people soy production could support in the average yard per year is $\mathrm{P}_{\text {soy }} /$ yard divided by $18.6 \mathrm{~kg}$.

\subsection{Scaled Protein Production Potential}

On average, Americans eat $88.7-107.7 \mathrm{~g}(3.13-3.80 \mathrm{oz})$ of meat per day, which is $32,400-39,300 \mathrm{~g}$ per year as shown by [69]:

$$
\mathrm{A}=\mathrm{G} \times 365[\mathrm{~g} / \text { year }]
$$

where $A$ is the number of grams of meat consumed per year and $G$ is the number of grams of meat consumed per day.

To fuel this demand for meat products, the U.S. produces 52 billion pounds ( 24 billion $\mathrm{kg}$ ) of meat for domestic consumption annually [69]. Most Americans are eating too much protein. From 2007 to 2010, 58\% of the U.S. population was eating above the optimal amount of protein rich foods, most of which are meats [70]. As a result of these and other eating trends, more than two-thirds of adults and almost one-third of children in the U.S. are overweight or obese [70].

The three approaches to backyard meat production are compared to show the grams of protein from each of the respective protein sources, the required protein source per household per year to obtain up to $100 \%$ of the nation's required protein, protein mass per household per year, and the percent of protein that the source could provide per household per year. These are then compared to the number of people backyard soybean production could support.

\subsection{Economics}

According to the USDA, the average whole chicken costs USD 1.28 per pound and the average live weight of a whole chicken is $8.2-11.7 \mathrm{lbs}$ [71]. Approximately $79 \%$ of live weight is retained from slaughter to sale or consumption of the bird. Thus, the typical weight of a processed chicken is $6.5-9.2 \mathrm{lbs}$. With these numbers, the average cost of one whole chicken ranges from USD 8.32 to USD 11.78. The average cost to raise one chicken per year with backyard costs is a culmination of costs of materials to build a coop, chicken feed, and of fertilized and sexed eggs.

If it is assumed that a chicken setup will be as basic as possible and the least expensive coop options are used, overall cost to raise any number of backyard chickens (3) is documented by the equations below:

$$
\begin{gathered}
\left.\mathrm{C}_{\text {initial }}=\mathrm{P}_{\text {chicken }} \times \mathrm{N}_{\text {chickens }} \text { [dollars }\right] \\
\mathrm{C}_{\text {feedyear }}=\mathrm{N}_{\text {chickens }} \times \mathrm{N}_{\text {months }} \times \mathrm{C}_{\text {chicken }}[\text { dollars }] \\
\left.\mathrm{C}_{\text {overall }}=\mathrm{C}_{\text {coop }}+\mathrm{C}_{\text {feedyear }}+\mathrm{C}_{\text {initial }} \text { [dollars }\right]
\end{gathered}
$$


where $P_{\text {chicken }}$ is the price per chick (in this case 5), $N_{\text {chickens }}$ is the number of chickens to be raised (in this case 3), $\mathrm{N}_{\text {months }}$ is the number of months in a year, $\mathrm{C}_{\text {chicken }}$ is the cost to feed one chicken for one year (in this case USD 2), $C_{\text {overall }}$ is the overall cost of raising a number of chickens for one year, $\mathrm{C}_{\text {coop }}$ is the cost of coop materials, $\mathrm{C}_{\text {feedyear }}$ is the cost of feeding a number of chickens for one year (each chicken requires approximately 2 dollars of feed every month), and $C_{\text {initial }}$ is the cost of purchasing 3 sexed eggs.

\section{Results}

\subsection{Pasture-Fed Rabbits}

\subsubsection{Pasture-Fed Rabbits Method 1}

For all calculations, a growing season of 180 days was used. The results of the analysis for grass-fed rabbits are shown in Figure 1. In New Hope, Oregon and other similar areas with Mountainous Areas, $\sim 90$ rabbits can be sustained per acre in a growing season. In New Brockton, Alabama and other similar areas with Red and Yellow Soils, $\sim 8$ rabbits can be sustained per acre in a growing season. In Irasburg, Vermont and other similar areas with Podsol Soils, $\sim 80$ rabbits can be sustained per acre in a growing season. In Botkins, Ohio and other similar areas with Gray Brown Podsolic Soils, $\sim 10$ rabbits can be sustained per acre in a growing season. In Nordic, Wyoming and similar areas with Brown and Dark Brown Soils, $\sim 70$ rabbits can be sustained per acre in a growing season. In Fairview, Kansas and similar areas with Chernozem and Prairie Soils, $\sim 3$ rabbits can be sustained per acre in a growing season. Across soil types, one acre can sustain 3-90 rabbits, meaning a half yard can sustain $0-11$ rabbits. This value would be greatly increased if rabbits were fed supplemental feed such as pellets or food scraps.

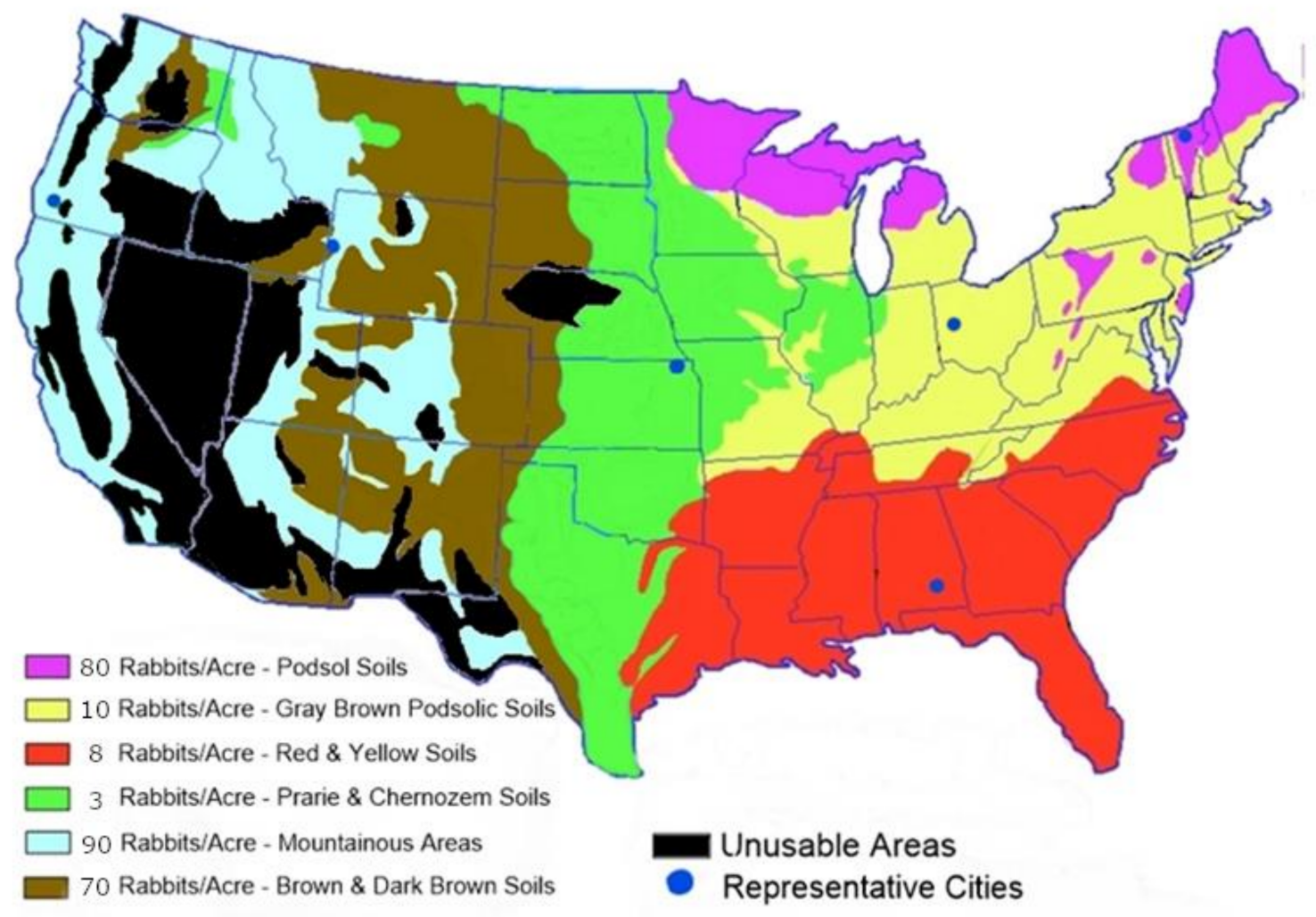

Figure 1. USA map with soil types and average production of rabbits per acre. Cities used for analysis via USDA Web Soil Survey are indicated. Areas considered unusable have little consistently growing vegetation and could sustain less than 1 rabbit per acre on average. Image adapted from [72]. 


\subsubsection{Pasture-Fed Rabbits Method 2}

With the second method, average lawn grass production for the U.S. is $1.08 \mathrm{~kg} / \mathrm{m}^{2}$ in a year. Most adult pet rabbits need $25 \mathrm{~g}(0.025 \mathrm{~kg})$ high fiber/low protein dry food per day per $1 \mathrm{~kg}$ body weight. It is assumed $3.2 \mathrm{~kg}$ average weight of rabbits, corresponding to $0.08 \mathrm{~kg}$ dry feed per day. This is a highly conservative estimate for the mass of a rabbit. Considering these two values and the average yard size in the US (404-505 $\left.\mathrm{m}^{2}\right)$, an average yard can support, $30-40$ rabbits during the growing season.

Another source [73] states that one rabbit requires approximately $46.5 \mathrm{~m}^{2}$ (500 square feet) of space with non-rotational grazing. With this estimate, 8-10 rabbits can fit in the average American yard and eat only grass. These numbers are roughly between methods 1 and 2.

\subsection{Pellet/Hay-Fed Rabbits}

Young rabbits need to be fed a combination of hay, pellets, and fresh vegetables to have a balanced diet and stimulate growth [48,74]. While the size of rabbit runs is not often factored into the area required to produce meat rabbits, rabbits' muscles will atrophy if they are not able to run daily and this will decrease the quality of meat obtained [52]. A small run is included in these calculations as described in the methods section above, but in general, the larger area a rabbit has to run, the healthier the rabbit will be. These values are a maximum allowed by space constraints and do not present a practical small-scale operation and should be used only if maximum meat production possible is required.

Depending on the rabbit, live weight can vary from 3-8 pounds and dress out to 2-4 pounds of usable meat [48]. Rabbit is an extremely lean meat with $100 \mathrm{~g}$ of meat containing $33.02 \mathrm{~g}$ of protein but only $3.51 \mathrm{~g}$ of fat [75]. As suggested by the USDA, a serving size of rabbit is $3 \mathrm{oz}(85 \mathrm{~g})$ which contains $28.1 \mathrm{~g}$ of protein and $2.98 \mathrm{~g}$ of fat [75].

Using the ranges given above and Equation (9), the range for $R_{\text {pellets/yard }}$ equals 117-191 rabbits per yard at a time.

Pellet-fed rabbits also have a much more consistent rate of growth than pasture fed rabbits. It is documented that an approximate ratio of 3 pounds of dry feed to 1 pound of wet body weight is a desirable and healthy rate of growth for meat rabbits [76].

It is assumed that pasture-fed rabbits and pellet-fed rabbits have the same nutritional value if raised until they are full grown. Since $100 \mathrm{~g}$ of rabbit meat has $33.02 \mathrm{~g}$ protein [75], one rabbit weighing 3-8 pounds (1.4-3.6 kg) live and dressing out to $2-4$ pounds $(0.9-1.8 \mathrm{~kg})$ [48] has 297-594 g protein. Using Equation (12), $1.37 \times 10^{10}$ (13.7 billion) rabbits would need to be produced to fulfill the protein requirements for the entire country for one year.

Using the range calculated in Section 2.2 and Equation (7), the average American backyard can raise a maximum of 117-191 rabbits at one time and a maximum of 468-764 rabbits per year. This range does not consider cold, snow, or other inclement weather that may occur seasonally in different locations. This range also does not consider spacing of cages to allow for access, maintenance, and transfer of animals from their cage to the run. This range is impractical and is only used in this study as a cap for the practical calculations in later sections.

\subsection{Pellet/Scrap-Fed Chickens}

Industry bred chickens are raised for 6-9 weeks before slaughter [71]. However, freerange and backyard raised chickens are often intended to be slower grown and can take 9-12 weeks before growing to full size for slaughter [77]. Egg laying hens are not generally slaughtered until 72 weeks [57]. For the purposes of this study, the process will be to obtain freshly hatched chicks or eggs that hatch on or around the first of each year. Chickens will be raised and fed throughout the entire year, beginning to collect eggs when they are produced around 18 weeks. Chickens will be slaughtered for meat on the last day of the year. 
This study examines chickens used for egg production for 1 year (35 weeks once chickens reach reproductive age) and slaughtered for meat, thus optimizing a chicken's egg production potential while limiting cost of feed and maintenance of raising a chicken for meat for longer than is necessary. Using the given range for American yard size and Equation (9), 376-468 pellet/scrap-fed chickens can be supported on half of an average yard at a maximum. This value is unrealistic and is used as a cap for more realistic values calculated in the upcoming sections.

\subsubsection{Chicken Protein}

The meat of one chicken provides about $140.8 \mathrm{~g}$ protein [71]. Using the equations above, 52 chickens per household would need to be produced to provide $100 \%$ of the nation's protein requirements for one year.

\subsubsection{Egg Protein}

One fresh large egg has $6.28 \mathrm{~g}$ protein [71]. A source state that in winter months, a chicken will produce as few as 2 eggs per week [78], and another says an average chicken produces 200-250 eggs per year [79] which amounts to $4-5$ eggs per week. Thus, the range of 2-5 eggs per week will be used as a more representative approach.

With the calculated value of 52 chickens per yard, $6370 \mathrm{~g}$ of protein could be produced per year with egg production. For calculations in Table 1, the range of 2-5 eggs is used to calculate protein and percentages, yielding a large range that includes $100 \%$. In Table 2, the range for egg production is averaged and a value of 3.5 eggs per week is used, leading to point values. With 52 chickens (using an average value of 3.5 eggs per week) and the equation below, $15 \%$ of the protein will be produced from meat and $84 \%$ of the protein will come from eggs.

Table 1. Protein Produced for Different Backyard Production Setups.

\begin{tabular}{|c|c|c|c|c|c|c|}
\hline & $\begin{array}{c}\text { Pasture-Fed } \\
\text { Rabbit }\end{array}$ & $\begin{array}{c}\text { Pellet-Fed } \\
\text { Rabbit }\end{array}$ & $\begin{array}{c}\text { Chicken } \\
\text { Meat }\end{array}$ & Eggs & $\begin{array}{c}\text { Chicken } \\
\text { Total }\end{array}$ & Soybeans \\
\hline Protein per raw item $(\mathrm{g})$ & $297-594$ & $297-594$ & 141 & 6.28 & $\mathrm{~N} / \mathrm{A}$ & 0.12 \\
\hline $\begin{array}{c}\text { Protein } \\
\text { source/household/year }\end{array}$ & $0-40$ & $470-760$ & $36-77$ & $2500-13,000$ & $\mathrm{~N} / \mathrm{A}$ & $\begin{array}{c}300,000- \\
610,000\end{array}$ \\
\hline $\begin{array}{c}\text { Total protein } \\
\text { (kg/year/household) }\end{array}$ & $0-20$ & $140-450$ & $5-11$ & $16-85$ & $21-96$ & $37-74$ \\
\hline $\begin{array}{l}\text { Percent of protein } \\
\text { requirement of US } \\
\text { population met }\end{array}$ & $0-50 \%$ & $300-1000 \%$ * & $11-23 \%$ & $33-180 \%$ & $44-203 \%$ & $78-160 \%$ \\
\hline
\end{tabular}

* Note: backyard filled for rabbits but not for chickens.

Table 2. Protein Produced for Pellet-Fed Rabbits and Chickens with Averages of Ranges.

\begin{tabular}{cccc}
\hline & $\begin{array}{c}\text { Rabbits with Averages } \\
\text { of Ranges }\end{array}$ & $\begin{array}{c}\text { Chickens with Averages } \\
\text { of Ranges }\end{array}$ & $\begin{array}{c}\text { Eggs with Averages } \\
\text { of Ranges }\end{array}$ \\
\hline Protein per raw item & $445.5 \mathrm{~g}$ & $140.8 \mathrm{~g}$ & $6.28 \mathrm{~g}$ \\
Protein source per household/year & 107 & 52 & 6370 \\
Kg Protein/year/household & 48 & 7.3 & 40 \\
Percent of Protein/year/US population & $100 \%$ & $15 \%$ & $85 \%$ \\
Combined animal & $100 \%$ & & $100 \%$ \\
\hline
\end{tabular}

\subsection{Soy Protein}

Soy production was found, as expected, to be a considerably more efficient use of backyard surface area. The value $\mathrm{m}_{\text {bean }}$ was experimentally found to be $0.58 \mathrm{~g}, \mathrm{n}_{\text {bean }}$ pod was 2.21, so $P_{\text {pod }}$ was found to be 0.1225 g protein per pod from Equation (18). Thus, the 
total soy protein per yard per year was found using Equation (19) to range from $37.15 \mathrm{~kg}$ and $74.21 \mathrm{~kg}$. It can be concluded that soybean production in the average American yard could support between two and four people for their protein needs throughout the year, which would thus put soy in the range of producing $100 \%$ of the protein needs for the average family.

\subsection{Scaled Protein Production Potential}

Table 1 uses Equations (1)-(11) to show the number of each animal that would need to be produced to obtain up to $100 \%$ of the required protein to feed the entire U.S. for one year. Because of the ranges in the values for the protein sources, the percentages are also given as a range (except in the case of chickens).

Maximum space calculations were performed in Equations (8)-(11) to determine the absolute maximum capacity of a yard. These values are not practical for most households and are used as a limit for the secondary calculations in Equations (12)-(17). For egg calculations, a range for 2-5 eggs per week is used to account for different climates in different locations. Some places in America have cold or otherwise inclement weather for a majority of the year and would be on the low range, while the southern parts of America have temperate or warm weather year-round and will be on the higher end of the range.

Table 2 details the number of animals required to produce $100 \%$ of a household's protein requirements for a year. The large range in percentage of protein/year for the U.S. population comes from the large range of protein values for many different breeds of meat rabbits. Because of the ranges in protein value, the range calculated for percent of protein per year for the U.S. population will contain 100\% without including it in either bound. The number of chickens required to produce $100 \%$ of the protein/year/household is used to calculate protein for the number of eggs produced leading to an inflated value. The range for chickens is also expanded by the addition of a range for egg production.

In Table 1, the ranges have not been eliminated and thus the ranges for percent protein provided include 100 within the range but do not contain exactly $100 \%$ in either of the ends of their range. Table 2 averages out all ranges to give one value for protein sources, thus presenting singular values for number of animals required for exactly $100 \%$ of total protein to be supplemented.

Table 3 describes the production statistics for eggs from 3 chickens collected over 1 year and the meat from 3 chickens, assuming they were slaughtered at the end of that year. Ranges in values come from the seasonal differences in egg production. During colder months, chickens produce fewer eggs (as low as 2 eggs per week) and during warmer months, chickens can produce up to 5 eggs per week [78,79]. These values were obtained by using 3 chickens for each of 128.58 million households in America, which is a realistic number of chickens held by representative small hobbyist chicken owners. The ranges come from 2-5 eggs per week being produced by each chicken. The process is shown by Equations (9)-(14). The value of 3 chickens was chosen based on averages compiled from backyard chicken farmers and scaled to account for the difference in access to farming materials and difference in yard size between a typical American home and that of a current backyard chicken farmer.

Table 3. Production Statistics for 3 Chickens Per Household.

\begin{tabular}{cc}
\hline National Average & Small Scale Chicken Operation \\
\hline Meat protein per household/year & 422.4 \\
Egg protein per household/year & $1959-4898 \mathrm{~g}$ \\
Protein/year/household & $2382-5321 \mathrm{~g}$ \\
Percent of protein/year/U.S. total need for protein & $3.7-7.8 \%$ \\
\hline
\end{tabular}

With Equations (9)-(14), 1741-3719 g of protein can be produced per year for each household if each household in America raises 3 chickens for one year. This value multiplied by 128.58 million households shows that between 223 billion and 478 billion grams of 
protein demand can be offset by the American population if 3 chickens are raised by each household in America for one year. With this equation and the ranges presented above, the percent of the American population that can have its protein requirements met by raising 3 chickens in every household backyard in America is 3.7-7.8\%.

\subsection{Economics}

Current backyard chicken setups generally range from 3-6 chickens [79-81]. In many backyard setups, however, chickens are raised only for eggs. Most homes in America have enough yard space to sustain a small operation such as this. If every home in America with sufficient space raised 3 egg and meat producing chickens per year, $3.66-7.83 \%$ of the protein produced in a year could be offset from the commercial meat industry (and a larger percentage of the commercial chicken egg market).

One of the aspects that makes chicken and egg production differently priced is the manual labor that is paid in an industry setting, but unpaid in a backyard setting. For a small backyard chicken setup, 1-2 h of labor are required per day [80]. As a setup grows, more time is required for cleaning, feeding, and maintenance.

The average American family, defined as two or more people living in the same household [82], spends USD 678 on meat in a year [83]. Startup costs for a free-range chicken vary from USD 200-4000 depending on local material cost and size of setup [81,84]. Yearly cost for a small chicken setup, assumed here to be 3 chickens, is USD 3-7/bird [79-81].

It also must be considered that all meat and eggs raised in this study are free range and organic if organic feed is used. Most chicken raised in America is factory scale and is therefore raised for significantly less money per bird due to feed costs being in bulk, less space required for each chicken, and bulk cost of maintenance, slaughtering materials, and coop space. One whole industry-produced chicken is generally sold for about USD 1.50 per pound in America, but organic chicken sold at stores such as Trader Joe's, Fresh Direct, and Whole Foods can range from USD 2.69-8.99 per pound [85].

The cost of eggs during non-pandemic times in mainland America averages USD 1.54 per dozen [86]. Similar to the higher values seen for organic meat, organic free-range eggs cost USD 4.00-7.00/dozen [87]. Further, feed is often sold for as little as 10 cents a pound, meaning that to sustain one chicken for one month, cost of feed is less than one dollar [78]. By another source, a 50-pound bag of chicken feed costs around USD 25 depending on location and quality of the feed, and can feed about 6 chickens for a month [80]. This source states that each chicken will need 8.3 pounds of feed per month, but cost for feed is dramatically different with feed for one chicken costing USD 4.15 for one month [80]. These differences in feed price will vary greatly depending on location, quality of feed, amount of feed purchased, and amount of feed required for each chicken due to the amount of supplemental food given.

Any other associated costs such as permits, veterinarian bills, slaughtering materials, cost of water and any other seasonally or regionally dependent costs are not taken into account in this model. For the purpose of this study, the following assumptions have been made: the cost of a coop is USD 200, USD 2 will feed one chicken for a month assuming that chickens are fed supplemental table scraps, insects, and weeds (a rough average according to the two sources quoted above) [78,80], and the initial cost of purchasing each chick is an average of USD $5[80,81]$. Based on these assumptions, the total cost of raising 3 chickens for one year comes to USD 287 and total cost of raising one chicken is therefore USD 96. This value is artificially inflated for long-term systems because the price of building a coop is a one-time cost and if chickens are raised for multiple consecutive years, the average cost will be much lower over time. In second and consecutive years, total cost will be, by the above calculations, about USD 29 per chicken per year with no labor cost.

The difference in cost of backyard-raised chicken when compared to store-bought chicken stems from the difference in price of food, price of coops or housing, and price to buy chickens. Industrial chickens are produced in mass quantities and food is bought in bulk which amounts to lower cost per chicken. Some chickens are also set aside as breeder 
chickens from birth. It can be asserted that backyard raised chickens are of higher value than store bought chicken because they are free-range, organic, and local, thus creating a value-added advantage to distributed production.

These equations and assumed values only work for a small-scale chicken operation. If the number of chickens to be raised exceeds 20 chickens (considered the upper bound for a typical backyard chicken operation) [79-81], a coop must be much larger and building materials will cost more. Assuming the 52 egg producing chickens required to satisfy $100 \%$ of one household's protein for one year were produced in a backyard, coop size would more than double from the small-scale operation (under 20 birds) and approximately double in cost (assuming the small-scale coop works for up to 20 chickens, but materials get cheaper per unit when bought in bulk). To gain a rough monetary estimate, cost for the coop will be increased to USD 400. The cost to raise 52 backyard chickens is then USD 1604 per year excluding coop cost as a one-time purchase. Per chicken, this value comes to be approximately USD 30.85. This is expensive when compared to industry-produced chickens, but it must be considered that this value takes into account not only the meat produced from one chicken, but also one year's worth of eggs (3-5 eggs per week for 35 weeks per year). This yields 105-175 eggs, which is approximately 9-15 dozen eggs. If all of these eggs were purchased at the above stated price of USD 1.54 per dozen, this would offset USD 13.86-23.10 from the overall cost of one chicken (USD 30.85) bringing the cost for the meat of one backyard chicken down to between USD 7.75-16.99. One whole chicken when purchased from a store costs between USD 8.32 and USD 11.78 for an average of USD 10.05. Industry chickens can be produced at a lower average cost because all aspects of production are performed in bulk, whereas with distributed production, all the externalities from centralized production are by definition ignored and egg production and meat production are separated to gain maximum product and profit for each.

The cost of raising non-pasture-fed rabbits is significantly greater than the previous two scenarios. Non-pasture fed rabbits require a mix of hay, pellets, and fresh vegetables to have a well-rounded diet. Rabbits consume $4-8$ ounces of pellets each day [88]. Cost of pellets varies depending on location but is usually around USD 15 per 50 pound $(22.7 \mathrm{~kg})$ bag [89]. If raised for 12 weeks until slaughter, $21-42$ pounds $(9.5-19.0 \mathrm{~kg})$ of feed are consumed. This means that the cost of feeding one rabbit for 12 weeks if feed costs USD 15 per 50-pound bag is USD 6.20-12.60. Since rabbits are currently not produced on an industrial scale in America, there is no direct comparison to backyard raised rabbits in the same sense that industrially raised chickens are compared to backyard chickens. However, in the areas where rabbit meat is produced, it is priced out to be USD 5-8/pound [73,90]. Dressed rabbits contain 2-4 pounds of usable meat [48]. The average store-bought rabbit will therefore cost between USD 10 and USD 28. This USD 3.80-15.40 difference in price between backyard-raised and store-bought rabbit means that much of the cost of storebought rabbit is labor of raising, transportation, and preservation of meat. In comparing these prices, only price of food was considered since that is the main reoccurring cost. This difference may also stem from commercial markups.

Soybeans can be purchased for USD 10.44 per bushel $(27.2 \mathrm{~kg})$ in the U.S. [91], which is approximately 38 cents per $\mathrm{kg}$.

\section{Discussion}

The differences in values for number of rabbits sustained via pasture grazing is due to different values in available data. Method 1 used the Web Soil Survey, which has limited data in certain areas of the country. These shortages of reliable data may lead to artificially low values. Method 2 used a grass growth analysis found in [50]. This study found growth rates of grass to be significantly different across the country and values were averaged for this study. This analysis may create an artificially high number of rabbits per yard. With the differences in values, the actual value of rabbits able to be sustained per yard is to be highly variable across the United States depending on specific soil type, grass type, native vegetation, yard maintenance, precipitation/irrigation and many other factors. It 
should also be considered that raising rabbits off of solely grass should only be used as an emergency farming method, and that rabbits will produce more and higher quality meat when grass feed is supplemented with pellets and vegetables [88].

The calculations in this study assume that the only source of protein consumed by Americans is meat/soybeans. Many other foods besides meat products such as beans, nuts, and grains contain high levels of protein and are already commonly consumed in combination with beef, pork, and chicken in the average American diet [70]. While the viability of plant-based diets is often contested, ample research shows that plant-based diets can sufficiently meet the protein needs of people during all stages of their life cycle, ranging from childhood to old age [22,92]. Approximately $1.5 \%$ of Americans follow vegetarian diets while $0.5 \%$ of Americans follow vegan diets [93], lowering the number of animals required to sustain the population.

When considering the growing demand for meat products worldwide and the potential stress on infrastructures and resources during pandemics, the long-term sustainability of meat production must be assessed. Diets dominated by meat products are the most energy-intensive and environmentally exhaustive [94]. Pimentel and Pimentel [95] show that the average American meat-based diet demands more energy, land, and water resources in comparison to an ovo-lacto vegetarian diet, which raises concern for the sustainability of current meat-based food systems and supports the need for a shift in dietary demands in the face of burgeoning global population and pandemics. While meat is generally thought of as the primary source of protein in developed countries, meat-based diets are unhealthy [96-98]. Vegetarian diets are associated with lower rates of death from ischemic heart disease, lower cholesterol levels, lower blood pressure, and lower rates of hypertension and type 2 diabetes [21,99].

The financial case for replacing a portion of the mass-produced meat in non-pandemic times is not entirely encouraging. However, in the raising of chickens, much of the cost comes in the form of startup materials. Options are in place in many areas to offset this cost for those who wish to raise chickens on a temporary basis in the form of renting coops and startup materials [81]. However, in times of crisis where a considerable portion of the meat market must significantly raise their prices, backyard raised animals may become much more cost efficient. The meat and poultry index rose by $4.3 \%$ nationwide in the month of March, when Coronavirus was officially declared a pandemic by the World Health Organization [100,101].

It must also be considered that the average yard size statistics used for this study may not represent an accurate picture of the number of rabbits to be raised for the entire country. The information represented in this study focuses on individual homes which does not represent the people who live in apartment style or communal housing without yards. The number of people excluded from this study because these living arrangements is estimated to be $17 \%$ of the population of the United States which equates to 55.8 million people [102].

For the systems presented in this study to be beneficial, support from local governments needs to be present. Many cities have restrictions on farm animals within city limits because of noise, odor, and spread of disease [103]. In the case of a partial national collapse of the commercial meat industry, a federal override of these municipal laws may be necessary. Certain areas of the country are already becoming more accepting of backyard animals, however, as is the case with San Antonio, Texas where the limit on backyard chickens was raised from three birds to eight in 2017 [79].

Another consideration on the accuracy of data from this study concerning pasture-fed rabbits is the longevity of the grass in American yards over a timespan of multiple years. Traditionally, people mow their lawns and leave grass clippings to decompose and fertilize the soil and promote more grass growth. If all this grass is eaten by pasture-fed rabbits and there is no influx of nutrients into the soil besides composted manure, the future growth of grass in those areas may suffer (some nutrients eaten by people would go into wastewater). This could be counteracted with fertilizer. 
Table 4 describes the resources required and outlines some of the basic environmental consequences of raising and producing each type of meat. Data regarding cows is also detailed here to give context to the environmental impact of each animal throughout a typical lifetime until slaughter. Production of beef requires substantially more resources than chicken, rabbit, or soybean production. The effects that the production of large amounts of beef has on the environment are becoming more apparent than ever as the global population grows [104]. Lytle et al. explain that the greenhouse gas emissions per $\mathrm{kg}$ of meat associated with cattle production is reduced by more than an order of magnitude when shifting to rabbit production [105].

Table 4. Resources Required to Produce Meat from Different Animals [43,55,106-111].

\begin{tabular}{ccc}
\hline Animal & Land Area (Acres) & $\mathbf{K g ~ C O}_{2}$ Equivalent Output per kg Meat \\
\hline Cattle & $1.5-2$ & $34.6[43,108]$ \\
Pasture-Fed Rabbit & $0.2-1.2$ & $0.0053[109]$ \\
Pellet-Fed Rabbit & $0.00069-0.00092$ & $3.86[106]$ \\
Chicken & 0.00032 & $4.57[55,110]$ \\
\hline
\end{tabular}

For $\mathrm{CO}_{2}$, beef produces around 7.57 times the carbon dioxide equivalent that chicken does. One reason for this difference is the fact that cattle only have one offspring at a time, so maintenance during gestation increases energy use. Production of backyard chickens or rabbits has significantly lower impact because of the lack of transport resources, lack of long-term refrigeration costs, and distributed preparation efforts.

The coronavirus (COVID-19) pandemic has overwhelmed medical and agricultural infrastructures at the regional level. During the coronavirus pandemic, meat packing plants were hotspots for coronavirus transfer and spread. The U.S. consumes $115-125 \mathrm{~kg}$ of animal meat (carcass weight) per capita annually [111] and 80\% of the meat industry is controlled by four companies $[19,20]$, presenting potentially crucial disruptions in meat supply chains and spurring the need to increase distributed production of meat for food resiliency during pandemics. Overall, to obtain $100 \%$ of a household's protein requirements only using the average backyard resources, the only viable solution from the results of this study is the cultivation of soybeans, which could provide between 37 and $74 \mathrm{~kg}$ of protein per year. Future work is needed to do a more detailed and granular assessment of backyards in America to see the regions where this would need to be supplemented or provide an excess. If external supplementation is available, the best option is raising chickens while also harvesting eggs. In this case if outside food was provided again chickens could provide all of the average household's protein needs using 52 chickens. Rabbits could also do this with about 107 rabbits using external feed. A smaller fraction (0-50\%) of the household's needs could be on average provided by pasture-fed rabbits using only the yard grass. Perhaps the best option is growing soybeans and feeding the residues to rabbits. These values are conservative for all cases. Both rabbits and chickens for example could be fed scraps to increase the yield. Future work is needed to experimentally verify yields for all protein sources investigated here. Data should be gathered studying the potential maximum number of chickens and rabbits in backyards in each state to identify the specific challenges related to high levels of meat production in space-constrained areas.

Household protein production could make sense for other catastrophes. One class of catastrophes would disrupt electricity/industry, and it includes extreme solar storm, high altitude detonation of a nuclear weapon causing an electromagnetic pulse, a super computer virus damaging electricity generating systems [112] or an extreme pandemic causing the desertion of critical industries [113]. In this case, food production would need to be much more local [114]. Soybean production from former lawns would be quite valuable, especially because it fixes nitrogen from the air, which is available for other crops.

Another class of catastrophes would kill crops, including by blocking the sun, caused by supervolcanic eruption, large comet/asteroid, or nuclear war causing the burning of cities and smoke rising into the stratosphere [114]. Though it may be feasible to relocate 
cold tolerant crops to the tropics, places such as the United States would have difficulty growing crops except indoors [115]. However, most of electricity and industry would still be functioning globally [116]. The existing biomass could form an important source of food. For instance, leaves can be ground up and the liquid that is squeezed out can be boiled to form a leaf protein concentrate [117]. It may be possible to break remaining cellulose into edible sugar at the household scale [118]. Regardless, the residues could be fed to fiber digesting animals including rabbits. Though a cow would typically not fit on a backyard, the biomass from multiple households could be consolidated to a cow. Mushrooms could also be grown in basements and are typically high in protein as a percent of calories. Residues from mushroom growing have already been fed to cattle, sheep, and bison [119], and would probably work for rabbits as well. Another protein option that could be grown at household scale is insects. Particularly valuable would be those insects that could feed on residues from leaf processing and also animal waste [120]. Another option for local food production in sunblocking catastrophes would be methane consuming microbes (single cell protein) because of continuing natural gas supply to houses. Similarly, if electricity is still flowing, it could be used to electrolyze water into oxygen and hydrogen. These could be combined by specialized microbes to create food [121,122]. Combination catastrophes could occur with the sun being blocked and electricity/industry being disabled [123]. In this case, only a subset of the alternative foods would be feasible, including leaf protein concentrate, mushrooms, and rabbits.

\section{Conclusions}

To safeguard against meat supply shortages, this study analyzed the potential to provide the average American household's entire protein consumption. Overall, to obtain $100 \%$ of a household's protein requirements only using the average sized backyard resources, soybean cultivation was found to provide between 37 and $74 \mathrm{~kg} /$ year, which is enough for two to four people. If external supplementation of feed is available, raising chickens while also harvesting the concomitant eggs as well as grain fed rabbits can meet $100 \%$ of a household's protein requirements. In these cases, 52 chickens and 107 rabbits would be needed, respectively. Using conservative yield estimates, however, only $0-50 \%$ of the household's needs could be on average provided by pasture-fed rabbits using only the yard grass as feed. Perhaps the best option is growing soybeans and feeding the residues to rabbits. These values are conservative for all cases and future work is needed to experimentally verify yields for all protein sources investigated here. Data should be gathered studying the potential maximum number of chickens and rabbits in backyards in each state to identify the specific challenges related to high levels of meat production in space-constrained areas.

For the systems presented in this study to be beneficial, support from local, and perhaps federal, government is needed to facilitate distributed meat production in response to a partial national collapse of the commercial meat industry during a pandemic. Resilience to future pandemics and challenges associated with growing meat demands can be incrementally addressed through backyard distributed protein production. Although backyard production of chicken and rabbit meat does not use feed or space as efficiently as current industry processes for these animals, environmental costs due to production, transportation, and refrigeration of meat products would be greatly reduced if more chicken and rabbit meat was consumed and even more so in the case of soybeans. Generally, distributed production of protein was found to be competitive with centralized production of meat if distributed labor costs were ignored. If raising protein by gardening or animal husbandry were not an enjoyable hobby for people, then one should include the opportunity cost of time. This would make backyard protein considerably more expensive; however, in the severe catastrophes where hunger or starvation is the alternative, these food sources could be critical. 
Author Contributions: Conceptualization, J.M.P.; methodology, T.K.M.; software, T.K.M.; validation, T.K.M., A.P., D.D. and J.M.P.; formal analysis, T.K.M.; investigation, T.K.M.; data curation, T.K.M.; writing—original draft preparation, T.K.M., J.M.P.; writing—review and editing, T.K.M., A.P., D.D., J.M.P.; visualization, T.K.M.; supervision, J.M.P.; funding acquisition, J.M.P. All authors have read and agreed to the published version of the manuscript.

Funding: This study was supported by the Witte Endowment.

Institutional Review Board Statement: Not applicable.

Informed Consent Statement: Not applicable.

Data Availability Statement: Available upon request.

Conflicts of Interest: The authors declare no conflict of interest.

\section{References}

1. Itzwerth, R.L.; MacIntyre, C.R.; Shah, S.; Plant, A.J. Pandemic influenza and critical infrastructure dependencies: Possible impact on hospitals. Med. J. Aust. 2006, 185. [CrossRef] [PubMed]

2. $\quad$ Fair, J.M.; Le Claire, R.J.; Wilson, M.L.; Turk, A.L.; De Land, S.M.; Powell, D.R.; Klare, P.C.; Ewers, M.; Dauelsberg, L.; Izraelevitz, D. An Integrated Simulation of Pandemic Influenza Evolution, Mitigation and Infrastructure Response. In Proceedings of the 2007 IEEE Conference on Technologies for Homeland Security, Woburn, MA, USA, 16-17 May 2007; IEEE: Woburn, MA, USA, 2007; pp. 240-245.

3. Williams, V.J. Fluconomics: Preserving Our Hospital Infrastructure during and after a Pandemic. Yale J. Health Policy Law Ethics 2007, 7, 99. [PubMed]

4. Adini, B.; Goldberg, A.; Cohen, R.; Bar-Dayan, Y. Relationship between equipment and infrastructure for pandemic influenza and performance in an avian flu drill. Emerg. Med. J. 2009, 26, 786-790. [CrossRef]

5. Homeland Security Council. National Strategy for Pandemic Influenza; Homeland Security Council: Washington, DC, USA, 2005.

6. World Health Organization Critical Preparedness, Readiness and Response Actions for COVID-19. Available online: https:/ / www.who.int/emergencies/diseases/novel-coronavirus-2019/technical-guidance/critical-preparedness-readinessand-response-actions-for-covid-19 (accessed on 31 March 2020).

7. Silv, M. COVID-19: Too little, too late? Lancet 2020, 395, 755. [CrossRef]

8. Nicola, M.; Alsafi, Z.; Sohrabi, C.; Kerwan, A.; Al-Jabir, A.; Iosifidis, C.; Agha, M.; Agha, R. The socio-economic implications of the coronavirus pandemic (COVID-19): A review. Int. J. Surg. 2020, 78, 185-193. [CrossRef] [PubMed]

9. Evans, B. Emergency preparedness: A veterinary and animal health community challenge......and obligation. Can. Vet. J. 2002, $43,797$.

10. Capua, I.; Alexander, D.J. The challenge of avian influenza to the veterinary community. Avian Pathol. 2006, 35, 189-205. [CrossRef]

11. McCarthy, R. Map: COVID-19 Meat Plant Closures. Available online: https://www.meatpoultry.com/articles/22993-covid-19 -meat-plant-map (accessed on 11 June 2020).

12. Dyal, J.W. COVID-19 Among Workers in Meat and Poultry Processing Facilities - 19 States, April 2020. Mmwr. Morb. Mortal. Wkly. Rep. 2020, 69. [CrossRef] [PubMed]

13. Dryden, J. Alberta Meat-Processing Plant Tied to Canada's Largest COVID-19 Outbreak to Reopen within Days. Available online: https:/ / www.cbc.ca/amp/1.5549774 (accessed on 18 June 2020).

14. Berta, T. Bienfar Registra un Bronte de Covid-19 en Dos Mataderos: 374 Trabajadores Cantagiados. Available online: https://www. elconfidencial.com/espana/2020-04-30/binefar-huesca-brote-coronavirus-mataderos-trabajadores-contagiados_2574440/ (accessed on 18 June 2020).

15. McSweeney, E. Covid-19 Outbreaks at Irish Meat Plants Raise Fears over Worker Safety. Available online: https://www. theguardian.com/environment/2020/may/01/covid-19-outbreaks-at-irish-meat-plants-raise-fears-over-worker-safety (accessed on 18 June 2020).

16. Mano, A. Nine Meat Plants in Southern Brazil Face COVID-19 Outbreaks. Available online: https:/ finance.yahoo.com/news / nine-meat-plants-southern-brazil-135725768.html (accessed on 18 June 2020).

17. ABC News. Coronavirus Cases Revealed in Victorian Paramedic and Cluster or Melbourne Abattoir Workers. Available online: https:/ / www.abc.net.au/news/2020-05-02/ coronavirus-cluster-melbourne-abbatoir-paramedic-tests-postive/12208560 (accessed on 18 June 2020).

18. Silverman, H. More than 370 Workers at a Pork Plant in Missouri Tested Positive for Coronavirus. All Were Asymptomatic. Available online: https://www.cnn.com/2020/05/04/us/triumph-foods-outbreak-missouri/index.html (accessed on 11 June 2020).

19. Ostlind, E. The Big Four Meatpackers-High Country News. Available online: https://www.hcn.org/issues/43.5/cattlemenstruggle-against-giant-meatpackers-and-economic-squeezes/the-big-four-meatpackers-1 (accessed on 25 June 2020).

20. Molteni, M. Why Meatpacking Plants Have Become Covid-19 Hot Spots. Available online: https://www.wired.com/story/whymeatpacking-plants-have-become-covid-19-hot-spots / (accessed on 23 June 2020). 
21. Kelly, D. Is It Better to Be a Vegetarian? Available online: https://www.webmd.com/diet/features/is-it-better-to-be-avegetarian\#1 (accessed on 10 August 2020).

22. Venderley, A.M.; Campbell, W.W. Vegetarian Diets. Sports Med. 2006, 36, 293-305. [CrossRef]

23. Pearce, J.M. Distributed Manufacturing of Open Source Medical Hardware for Pandemics. J. Manuf. Mater. Process. 2020, 4, 49. [CrossRef]

24. Skrzypczak, N.G.; Tanikella, N.G.; Pearce, J.M. Open Source High-Temperature RepRap for 3-D Printing Heat-Sterilizable PPE and Other Applications. HardwareX 2020, 8, e00130. [CrossRef]

25. Hubbard, B.R.; Pearce, J.M. Conversion of Self-Contained Breathing Apparatus Mask to Open Source Powered Air-Purifying Particulate Respirator for Fire Fighter COVID-19 Response. HardwareX 2020, 8, e00129. [CrossRef]

26. Shokrani, A.; Loukaides, E.G.; Elias, E.; Lunt, A.J.G. Exploration of alternative supply chains and distributed manufacturing in response to COVID-19; a case study of medical face shields. Mater. Des. 2020, 192, 108749. [CrossRef]

27. Tino, R.; Moore, R.; Antoline, S.; Ravi, P.; Wake, N.; Ionita, C.N.; Morris, J.M.; Decker, S.J.; Sheikh, A.; Rybicki, F.J.; et al. COVID-19 and the role of 3D printing in medicine. 3D Print. Med. 2020, 6, 11. [CrossRef]

28. Novak, J.I.; Loy, J. A critical review of initial 3D printed products responding to COVID-19 health and supply chain challenges. Emerald Open Res. 2020, 2, 24. [CrossRef]

29. Pearce, J.M. A review of open source ventilators for COVID-19 and future pandemics. F1000Research 2020, 9, 218. [CrossRef] [PubMed]

30. Callahan, C.J.; Lee, R.; Zulauf, K.; Tamburello, L.; Smith, K.P.; Previtera, J.; Cheng, A.; Green, A.; Azim, A.A.; Yano, A.; et al. Open Development and Clinical Validation of Multiple 3D-Printed Sample-Collection Swabs: Rapid Resolution of a Critical COVID-19 Testing Bottleneck. medRxiv 2020. [CrossRef]

31. Gallup, N.; Pringle, A.M.; Oberloier, S.; Tanikella, N.G.; Pearce, J.M. Parametric Nasopharyngeal Swab for Sampling COVID-19 and Other Respiratory Viruses: Open Source Design, SLA 3-D Printing and UV Curing System. HardwareX 2020, 8 , e00135. [CrossRef] [PubMed]

32. Wittbrodt, B.T.; Glover, A.G.; Laureto, J.; Anzalone, G.C.; Oppliger, D.; Irwin, J.L.; Pearce, J.M. Life-Cycle Economic Analysis of Distributed Manufacturing with Open-Source 3-D Printers. Mechatronics 2013, 23, 713-726. [CrossRef]

33. Griffith, G. It's easier to find gold than hens in lockdown. BBC News, 23 May 2020.

34. Cunningham, M. Trending Now: Chicken Keeping. Crozet Gazette, 18 May 2020.

35. Jones, S. Coronavirus Spurs Record Sales and Rentals of Baby Chicks at Berks-Area Sites. Available online: https: //www.readingeagle.com/berks-country / coronavirus-spurs-record-sales-and-rentals-of-baby-chicks-at-berks-area-sites / article_e6bf10a6-9ab7-11ea-bab2-c3e4ffdbcad8.html (accessed on 11 June 2020).

36. Davies, E. People Rush to Raise Backyard Chickens Amid Egg Shortages, Coronavirus Concerns. Available online: https: / / www.washingtonpost.com/local/people-rush-to-raise-backyard-chickens-amid-egg-shortages-coronavirus-concerns / 2020 /03/30/b9d4d3ea-71d7-11ea-a9bd-9f8b593300d0_story.html (accessed on 22 June 2020).

37. Graber, R. Will COVID-19 Fears Prompt More Backyard Egg Production? Available online: https://www.wattagnet.com/blogs/ 27-agrifood-angle/post/39922-will-covid-19-fears-prompt-more-backyard-egg-production (accessed on 29 June 2020).

38. Picchi, A. Seed Companies Can't Keep Up as More Americans Turn to Growing Their Own Food. Available online: https: //www.cbsnews.com/news/coronavirus-seeds-americans-grow-food/ (accessed on 8 May 2020).

39. Mark, M. People Are Rushing to Plant "Pandemic Gardens" and Seed Companies Say They Can't Keep Up with the Surge in Demand. Available online: https:/ / www.insider.com/seed-companies-cant-keep-up-with-demand-for-pandemic-gardens-20 20-4 (accessed on 11 September 2020).

40. Pym, R.A.; Alders, R.G. Introduction to village and backyard poultry production. Altern. Syst. Poult. Health Welf. Product. 2012, 97-109. [CrossRef]

41. Milesi, C.; Running, S.W.; Elvidge, C.D.; Dietz, J.B.; Tuttle, B.T.; Nemai, R.R. Mapping and Modeling the Biogeochemical Cycling of Turf Grasses in the United States. Environ. Manag. 2005, 36, 426-438. [CrossRef]

42. HomeAdvisor. The United States Ranked by Yard Size. Available online: https://www.homeadvisor.com/r/average-yard-sizeby-state/ (accessed on 23 June 2020).

43. FAO. Livestock's Long Shadow. Environ. Issues Options 2006.

44. Elferink, E.V.; Nonhebel, S. Variations in land requirements for meat production. J. Clean. Prod. 2007, 15, 1778-1786. [CrossRef]

45. USDA. Web Soil Survey. Available online: https://websoilsurvey.sc.egov.usda.gov/App/HomePage.htm (accessed on 1 June 2020).

46. Undersander, D.; SaxeField, C. Drying Forage for Hay and Haylage. Focus Forage 2013, 12. Available online: https:// fyi.extension. wisc.edu/forage/drying-forage-for-hay-and-haylage/ (accessed on 31 March 2021).

47. The Rabbit House. Rabbit Hutch/Cage Size Guide. Available online: http:/ / www.therabbithouse.com/guide_size.asp (accessed on 26 July 2020).

48. Mather, R. Rabbit: A Great Meat Animal for Small Homesteads I MOTHER EARTH NEWS. Available online: https://www. motherearthnews.com/homesteading-and-livestock/raising-rabbits/meat-rabbits-zm0z11zmat (accessed on 12 June 2020).

49. Garnier, E.; Laurent, G. Leaf Anatomy, Specific Mass and Water Content in Congeneric Annual and Perennial Grass Species. New Phytol. 1994, 128, 725-736. [CrossRef]

50. Falk, J.H. The Primary Productivity of Lawns in a Temperate Environment. J. Appl. Ecol. 1980, 17, 689-695. [CrossRef] 
51. Rogers, C.D. How Big is the Average Backyard and Other Stats About American Homes. Available online: https://www. owntheyard.com/how-big-is-the-average-backyard/ (accessed on 30 June 2020).

52. The Omlet Blog. How Much Space Does a Rabbit Need? Available online: https://www.omlet.us/guide/rabbits/rabbit_ hutches/how_much_space/ (accessed on 26 July 2020).

53. Ockert, K.; Michigan State University Extension. Determining Cage Size for Rabbits. Available online: https://www.canr.msu. edu/news/determining_cage_size_for_rabbits (accessed on 26 July 2020).

54. Trampel, D.W.; Frank, M.; Evans, K.; Barnes, H.J. Chapter 1: Broiler Industry, Poultry Industry Manual. In Poultry Industry Manual: FAD PReP National Animal Health Emergency Management System; USDA: Buckeye, AZ, USA, 2013; Volume 19, pp. 23-24.

55. Miele, M. The Taste of Happiness: Free-Range Chicken. Environ. Plan A 2011, 43, 2082-2083. [CrossRef]

56. Ballotpedia. Egg Prices by State. 2018. Available online: https://ballotpedia.org/Egg_prices_by_state,_2018 (accessed on 2 July 2020).

57. Bain, M.M.; Nys, Y.; Dunn, I.C. Increasing Persistency in Lay and Stabilizing Egg Quality in Longer Laying Cycles. What Are the Challenges? Br. Poult. Sci. 2016, 57, 330-338. [CrossRef]

58. Khawaja, T.; Khan, S.H.; Mukhtar, N.; Parveen, A.; Fareed, G. Production Performance, Egg Quality and Biochemical Parameters of Three Way Crossbred Chickens with Reciprocal $F_{1}$ Crossbred Chickens in Sub-Tropical Environment. Ital. J. Anim. Sci. 2013, 12. [CrossRef]

59. Pritchard, F. What Is 'Free-Range Chicken'? Available online: https://smithmeadows.com/farm/what-is-free-range-chicken/ (accessed on 23 June 2020).

60. Gunnars, K. Protein Intake-How Much Protein Should You Eat Per Day? Available online: https://www.healthline.com/ nutrition/how-much-protein-per-day (accessed on 29 June 2020).

61. United States Census Bureau. Population Estimates. Available online: https://www.census.gov/glossary/\#term_ Populationestimates (accessed on 30 July 2020).

62. Statista. U.S. Number of Households 1960-2019. Available online: https://www.statista.com/statistics/183635/number-ofhouseholds-in-the-us/ (accessed on 15 July 2020).

63. Reijnders, L.; Soret, S. Quantification of the Environmental Impact of Different Dietary Protein Choices. Am. J. Clin. Nutr. 2003, 78, 664S-668S. [CrossRef]

64. Liu, K. Chemistry and Nutritional Value of Soybean Components. In Soybeans: Chemistry, Technology, and Utilization; Springer: Boston, MA, USA, 1997; pp. 25-113.

65. Raman, R. How Much Protein in Chicken? Breast, Thigh and More. Available online: https://www.healthline.com/nutrition/ protein-in-chicken\#: \{\}:text=Summary\%20One\%20chicken\%20breast \%20contains, while\%2020\%25\%20comes \%20from\%20fat (accessed on 16 August 2020).

66. Albert, S. How to Grow Soybeans. Available online: https://harvesttotable.com/how_to_grow_soybean/ (accessed on 10 August 2020).

67. Lee, C.; Herkbek, J.; University of Kentucky. Estimating Soybean Yield. Available online: http:/ /www2.ca.uky.edu/agcomm/ pubs/agr/agr188/agr188.pdf (accessed on 14 August 2020).

68. Great Value. Edamame, Walmart Grocery. Available online: https://www.walmart.com/grocery/ip/Great-Value-Edamame-12 -oz/328567678 (accessed on 11 September 2020).

69. North American Meat Institute (NAMI). The Unites States Meat Industry at a Glance. Available online: https://www. meatinstitute.org/index.php?ht=d/sp/i/47465/pid/47465 (accessed on 25 June 2020).

70. US Department of Health and Human Services, Office of Disease Prevention and Health Promotion, (Health.gov). Current Eating Patterns in the United States- 2015-2020 Dietary Guidelines. Available online: https:/ /health.gov/our-work/food-nutrition/20 15-2020-dietary-guidelines/guidelines/chapter-2/current-eating-patterns-in-the-united-states/ (accessed on 29 July 2020).

71. Haley, M. Livestock, Dairy, and Poultry Outlook: December 2017. Available online: http://www.ers.usda.gov/publications/pubdetails / ?pubid=86242 (accessed on 23 June 2020).

72. Ricker, R.E. Analysis of Pipeline Steel Corrosion Data From NBS (NIST) Studies Conducted between 1922-1940 and Relevance to Pipeline Management; National Institute of Standards and Technology: Gaithersburg, Montgomery, 2007; pp. 1-71.

73. Pascaris, A.S.; Schelly, C.; Pearce, J.M. A First Investigation of Agriculture Sector Perspectives on the Opportunities and Barriers for Agrivoltaics. Agronomy 2020, 10, 1885. [CrossRef]

74. Rabin, M. Consider the Rabbit-Modern Farmer. Available online: https://modernfarmer.com/2019/03/consider-the-rabbit/ (accessed on 23 June 2020).

75. USDA, Game Meat, Rabbit, Wild, Cooked, Stewed. FoodData Central. Available online: https://fdc.nal.usda.gov/fdc-app.html\# / food-details / 174348/nutrients (accessed on 18 June 2020).

76. MSU Extension. Rabbit Tracks: Feeds and Feeding. Available online: https://www.canr.msu.edu/resources/rabbit_tracks_ feeds_and_feeding (accessed on 25 September 2020).

77. Jacob, J. Raising Meat Chickens in Small or Backyard Flocks. Available online: https://poultry.extension.org/articles/poultrymanagement/raising-meat-chickens-in-small-or-backyard-flocks/ (accessed on 24 August 2020).

78. Vivian, J. Raising Free-Range Chickens-Sustainable Farming. Available online: https://www.motherearthnews.com/ homesteading-and-livestock/raising-free-range-chickens-zmaz84jazloeck (accessed on 23 June 2020). 
79. Blount, C. San Antonians Fix Egg Shortages by Hoarding Chickens in Addition to Toilet Paper because of the Coronavirus. Available online: https://www.expressnews.com/food/article/San-Antonians-fix-egg-shortages-by-hoarding-15177934.php (accessed on 6 July 2020).

80. Collins-McKenzie, C. Raising Chickens 101-How to Raise Happy Chickens. Available online: https:/ /www.countryliving.com/ life/kids-pets/a32102474/raising-chickens / (accessed on 18 June 2020).

81. Videtti, A. Egg-Onomics: The Real Cost of Raising Backyard Chickens. Available online: https://www.alliantcreditunion.org/ money-mentor/egg-onomics-the-real-cost-of-raising-backyard-chickens (accessed on 23 June 2020).

82. US Census Bureau. Subject Definitions. Available online: https://www.census.gov/programs-surveys/cps/technicaldocumentation/subject-definitions.html (accessed on 13 July 2020).

83. Price, S. Average Household Cost of Food. Available online: https://www.valuepenguin.com/how-much-we-spend-food (accessed on 5 June 2020).

84. Josephson, A. The Economics of Raising Chickens. Available online: https://smartasset.com/personal-finance/the-economicsof-raising-chickens (accessed on 18 June 2020).

85. Reuters. Is Organic Chicken Worth The Price? Available online: https://www.reuters.com/article/us-money-chicken-organicidUSKBNOFM24Q20140717 (accessed on 8 September 2020).

86. Statista. Retail Price of Eggs (Grade A, Large) in the United States from 1995 to 2019. Available online: https: / / www.statista. com/statistics/236852/retail-price-of-eggs-in-the-united-states/ (accessed on 20 July 2020).

87. Horgan, K. How Much Do You Pay For A Dozen Organic Eggs? [Update] I Giving Assistant. Available online: https: //blog.givingassistant.org/how-much-do-you-pay-for-a-dozen-organic-eggs/ (accessed on 11 September 2020).

88. Rise and Shine Rabbitry. Pellets and Nutrition for Meat Rabbits. Available online: https://riseandshinerabbitry.com/2012/05/23 / pellets-and-nutrition-for-meat-rabbits/ (accessed on 29 July 2020).

89. Tractor Supply Company. Producer's Pride Rabbit Feed 50 lb. Available online: https://www.tractorsupply.com/tsc/product/ producers-pride-rabbit-feed-50-lb (accessed on 29 July 2020).

90. Martucci, B. Raising Rabbits for Meat-Cost, Legalities \& How to Start Farming. Available online: https://www.moneycrashers. $\mathrm{com} /$ raising-rabbits-meat-farming/\#: \{\}:text=If \%20you $\backslash$ T1 $\backslash$ textquoterightre $\% 20$ able $\% 20$ to, willing $\% 20$ to $\% 20$ purchase $\% 20$ small\%20batches (accessed on 19 August 2020).

91. Markets Insider. Soybeans Price Today. Available online: https://markets.businessinsider.com/commodities/soybeans-price (accessed on 20 September 2020).

92. Leitzmann, C. Vegetarian Diets: What are the Advantages? In Diet Diversification and Health Promotion; Karger Publishers: Basel, Switzerland, 2005; Volume 57, pp. 147-156.

93. Lane How Many Vegans in the World? In the USA? (2020). Vegan Bits 2020. Available online: https://veganbits.com/vegandemographics / (accessed on 29 July 2020).

94. Dagevos, H.; Voordouw, J. Sustainability and meat consumption: Is reduction realistic? Sustain. Sci. Pract. Policy 2013, 9, 60-69. [CrossRef]

95. Pimentel, D.; Pimentel, M. Sustainability of Meat-Based and Plant-Based Diets and the Environment. Am. J. Clin. Nutr. 2003, 78, 660S-663S. [CrossRef] [PubMed]

96. Song, M.; Fung, T.T.; Hu, F.B.; Willett, W.C.; Longo, V.D.; Chan, A.T.; Giovannucci, E.L. Association of Animal and Plant Protein Intake with All-Cause and Cause-Specific Mortality. JAMA Intern. Med. 2016, 176, 1453-1463. [CrossRef] [PubMed]

97. Abete, I.; Romaguera, D.; Vieira, A.R.; de Munain, A.L.; Norat, T. Association between total, processed, red and white meat consumption and all-cause, CVD and IHD mortality: A meta-analysis of cohort studies. Br. J. Nutr. 2014, 112, 762-775. [CrossRef] [PubMed]

98. Bernstein, A.M.; Sun, Q.; Hu, F.B.; Stampfer, M.J.; Manson, J.E.; Willett, W.C. Major dietary protein sources and risk of coronary heart disease in women. Circulation 2010, 122, 876-883. [CrossRef] [PubMed]

99. Kim, H.; Caulfield, L.E.; Garcia-Larsen, V.; Steffen, L.M.; Coresh, J.; Rebholz, C.M. Plant-Based Diets Are Associated With a Lower Risk of Incident Cardiovascular Disease, Cardiovascular Disease Mortality, and All-Cause Mortality in a General Population of Middle-Aged Adults. J. Am. Heart Assoc. 2019, 8, e012865. [CrossRef] [PubMed]

100. Johansson, R. (USDA) Another Look at Availability and Prices of Food Amid the COVID-19 Pandemic. Available online: https: //www.usda.gov/media/blog/2020/05/28/another-look-availability-and-prices-food-amid-covid-19-pandemic (accessed on 6 July 2020).

101. Centers for Disease Control and Prevention. New ICD-10-CM Code for the 2019 Novel Coronavirus (COVID-19), 1 April 2020. Available online: https://www.cdc.gov/nchs/data/icd/Announcement-New-ICD-code-for-coronavirus-3-18-2020.pdf (accessed on 6 July 2020).

102. O'Malley, C. 80 Percent of Americans Prefer Single Family Homeownership. Available online: https://www.builderonline.com/ money/economics /80-percent-of-americans-prefer-single-family-homeownership_o (accessed on 22 June 2020).

103. Karcher, D. Suggestions for Ordinances Allowing Backyard Poultry (E3136). Available online: https://www.canr.msu.edu/ resources/suggestions_for_ordinances_allowing_backyard_poultry_by_darren_karcher_sku (accessed on 1 July 2020).

104. Capper, J.L. The Environmental Impact of Beef Production in the United States: 1977 Compared with 2007. J. Anim. Sci. 2011, 89, 4249-4261. [CrossRef] [PubMed] 
105. Lytle, W.; Meyer, T.K.; Tanikella, N.G.; Burnham, L.; Engel, J.; Schelly, C.; Pearce, J.M. Conceptual Design and Rationale for a New Agrivoltaics Concept: Pasture-Raised Rabbits and Solar Farming. J. Clean. Prod. 2021, 282, 124476. [CrossRef]

106. Franz, R.; Soliva, C.R.; Kreuzer, M.; Hummel, J.; Clauss, M. Methane output of rabbits (Oryctolagus cuniculus) and guinea pigs (Cavia porcellus) fed a hay-only diet: Implications for the scaling of methane production with body mass in non-ruminant mammalian herbivores. Comp. Biochem. Physiol. 2011, 158, 177-181. [CrossRef]

107. Daniel, C.R.; Cross, A.J.; Koebnick, C.; Sinha, R. Trends in meat consumption in the USA. Public Health Nutr. 2011, 14, 575-577. [CrossRef] [PubMed]

108. Time For Change. The Impact of Meat to Global Warming-Methane and CO2. Available online: https://timeforchange.org/arecows-cause-of-global-warming-meat-methane-co2/ (accessed on 23 June 2020).

109. Pascaris, A.S.; Handler, R.; Schelly, C.; Pearce, J.M. Life Cycle Assessment of Pasture-based Agrivoltaic Systems: Synergies \& Sustainability. to be published.

110. Smil, V. Eating Meat: Evolution, Patterns, and Consequences. Popul. Dev. Rev. 2002, 28, 599-639. [CrossRef]

111. Abdelkhaliq, M.; Denkenberger, D.; Cole, D.D.; Griswold, M.; Pearce, J. Providing Non-Food Needs if Industry is Disabled. In Proceedings of the 6th International Disaster and Risk Conference, Davos, Switzerland, 28 August-1 September 2016.

112. Manheim, D.; Denkenberger, D. Review of Potential High-Leverage and Inexpensive Mitigations for Reducing Risk in Epidemics and Pandemics. J. Glob. Health Rep. 2020, 4. [CrossRef]

113. Cole, D.D.; Denkenberger, D.; Griswold, M.; Abdelkhaliq, M.; Pearce, J. Feeding Everyone if Industry is Disabled. In Proceedings of the 6th International Disaster and Risk Conference, Davos, Switzerland, 28 August-1 September 2016.

114. Denkenberger, D.C.; Pearce, J.M. Cost-effectiveness of interventions for alternate food in the United States to address agricultural catastrophes. Int. J. Disaster Risk Reduct. 2018, 27, 278-289. [CrossRef]

115. Alvarado, K.A.; Mill, A.; Pearce, J.M.; Vocaet, A.; Denkenberger, D. Scaling of greenhouse crop production in low sunlight scenarios. Sci. Total Environ. 2020, 707, 136012. [CrossRef]

116. Denkenberger, D.C.; Pearce, J.M. Feeding everyone: Solving the food crisis in event of global catastrophes that kill crops or obscure the sun. Futures 2015, 72, 57-68. [CrossRef]

117. Pearce, J.M.; Khaksari, M.; Denkenberger, D. Preliminary automated determination of edibility of alternative foods: Non-targeted screening for toxins in red maple leaf concentrate. Plants 2019, 8, 110. [CrossRef] [PubMed]

118. Denkenberger, D.; Pearce, J.M. Feeding everyone no matter what: Managing food security after global catastrophe. Acad. Press. 2014. Available online: https:/ / www.sciencedirect.com/book/9780128044476/feeding-everyone-no-matter-what (accessed on 1 April 2021).

119. Spinosa, R. Fungi and sustainability. Fungi 2008, 138-143. Available online: http://www.fungimag.com/spring-08-articles/ sustainability.pdf (accessed on 1 April 2021).

120. Denkenberger, D.; Taylor, A.; Black, R.; Pearce, J. Food without Sun: Price and Life-Saving Potential. Foresight 2019, 21, 118-129. [CrossRef]

121. Alvarado, K.A.; García Martínez, J.B.; Matassa, S.; Egbejimba, J.; Denkenberger, D.C. Food in space from hydrogen oxidizing bacteria. Undergoing Revis. Acta Astronaut. 2021, 180, 260-265. [CrossRef]

122. García Martínez, J.B.; Egbejimba, J.; Throup, J.; Matassa, S.; Pearce, J.M.; Denkenberger, D.C. Potential of microbial protein from hydrogen for preventing mass starvation in catastrophic scenarios. Sustain. Prod. Consum. 2021, 25, 234-247. [CrossRef] [PubMed]

123. Denkenberger, D.C.; Cole, D.D.; Abdelkhaliq, M.; Griswold, M.; Hundley, A.B.; Pearce, J.M. Feeding everyone if the sun is obscured and industry is disabled. Int. J. Disaster Risk Reduct. 2007, 21, 284-290. [CrossRef] 